Mateja Jemec Tomazin

InŠTITUT ZA SLOVENSKI JeZIK FRANA RAMOVŠa ZRC SAZU

LJUBLJANA, SLOVENIJA

mjt@zrc-sazu.si

https://doi.org/10.17234/9789531755139.29

\title{
KDAJ JE DOBRO POSTATI TRMAST KOT VOL? Živalski frazemi v pravnih strokovnih besedilih
}

\begin{abstract}
$\mathrm{V}$ prispevku bomo predstavili živalske frazeme, ki se pojavljajo v strokovni pravni literaturi. Raba katerihkoli frazemov v strokovnih besedilih je vedno odvisna predvsem od avtorskega sloga slehernega avtorja, zaradi teženja k znanstvenosti, tehtnosti in prepričljivosti pa je tudi pri morebitni rabi frazemov zelo pomembna kulturološka konotacija rabljenih sestavin frazema, kar pomeni, da prihaja do zamenjav živali, če naj bi bilo besedilo bolj strokovno (npr. vztrajen kot želva in ne vztrajen kot vol).
\end{abstract}

Ključne besede: živalski frazemi, konotacija frazemov, frazemske sestavine, znanstveni slog, osebni slog

\section{Uvod}

Stilistika strokovnih oz. znanstvenih besedil lahko predstavlja skorajda oksimoron, saj naj bi bil glavni namen tovrstnih besedil predstavitev novih spoznanj, njihovo utemeljevanje, razčlenjevanje in ne nazadnje prepričevanje, ki naj bi temeljilo predvsem na dejstvih. Doseganje teh ciljev naj bi omogočala čim bolj jasna, natančno strukturirana besedila, ki naj bi bila skladenjsko preprostejša zaradi količin novih podatkov. Do neke mere ta izhodišča veljajo za tista strokovna besedila, ki predstavljajo izsledke meritev, analiz, opise novih tehnologij, torej za razprave in članke naravoslovnih, (vse) manj pa družboslovnih in humanističnih znanosti. Glavno orodje (in orožje) prava je jezik, zato so izvirne ${ }^{1}$ in vedno drugačne stilistične figure ne le običajen, ampak tudi pričakovan del tovrstnih besedil. Pri tem se oblikuje bolj ali manj prepoznaven (osebni) slog avtorjev, s tem pa tudi določene strokovne revije, kar spodbudi druge avtorje, da uporabljajo (ali si dovolijo uporabljati) za strokovna besedila doslej manj pričakovan osebni slog. ${ }^{2}$

I Izvirnost je seveda do neke mere omejena, saj mora avtor upoštevati naslovnika (in njegovo predznanje), če želi, da bo aktualizacija frazema oz. njegova prenovitev razumljena in je naslovnik ne bo imel za napako, npr. Sreča je za aristokrate, pravo pa za krave v hlevu kot parodija na izjavo Boštjana M. Zupančiča Sreča je za krave v hlevu, pravo pa za aristokrate (PP, 11. 11. 2010, str. 33).

2 Izrazit osebni slog je viden tudi v članku (sicer aktualizirani oceni knjige) Marka Pavlihe: John Grisham dvajsetič: Igranje za pico: »Sreča je opoteča, slava pa minljiva, za kar znatno poskrbijo mediji, ki uspevajo zaradi slabih novic. Bolje je biti kralj na vasi kot hlapec $\mathrm{v}$ mestu ali po angleško, raje velika riba v majhnem ribniku kot majčkena $\mathrm{v}$ večjem. Boljši je vrabec v roki kot golob na strehi oziroma $\mathrm{v}$ dobesednem kontekstu pričujočega romana - privoščimo si pico na krožniku in pozabimo na kaviar v izložbi. Res je, da prijatelja spoznaš v nesreči, vendar je v vsakem altruizmu tudi kanček egoizma. Ljubezen gre skozi želodec, pri čemer ni dobro pretiravati s pijačo.« (PP, 22. 11. 2007, str. 31) 
Gruber/Huemer/Rheindorf (2009: 64-66) govorijo celo o t. i. znanstvenih kulturah, pri čemer naj bi posebno stilistiko in $\mathrm{s}$ tem meje dopustnega $\mathrm{v}$ znanstveni periodiki pogojevala tako veda sama kot tudi tradicija posamezne države (npr. Anglija in Francija $\mathrm{z}$ drugačno tradicijo tvorjenja znanstvenih besedil od nemške). Elemente osebno prepoznavnega oz. avtorskega sloga lahko poimenujemo z izrazom esejističnost (več v Jemec Tomazin 2012: 81-90).

\section{Metodologija}

Za namen prispevka smo oblikovali korpus, ${ }^{3}$ ki obsega pravniški časopis Pravna praksa $^{4}$ (dalje PP) od leta 2005 do leta 2012 in znanstveno revijo Pravnik ${ }^{5}$ od leta 2008 do leta 2012, oba naslova sodita med najbolj brano in razširjeno slovensko pravno periodiko, oba uporabljata sprotne opombe (v vseh tipih besedil, tudi kolumnah) in navajanje literature na koncu strokovnega članka.

Pri iskanju frazemov smo bili pozorni na obliko (in morebitne pretvorbe) živalskih frazemov, pogostost njihovega pojavljanja, mesto, kjer se v besedilu pojavljajo, tip besedila (ali gre za uvodnik, kolumno ali strokovni/znanstveni prispevek) in ne nazadnje tudi na avtorje, ki si (živalske) frazeme »dovolijo uporabljati«.

\subsection{Tipi slogovnih figur $v$ pravniških znanstvenih revijah}

Za podrobno analizo stilnih figur $\mathrm{v}$ strokovnih/znanstvenih besedilih bi potrebovali samostojen prispevek, vendar se (tudi glede na tip revije oz. časopisa) oblikujejo prepoznavni tipi slogovnih figur. Tako so živali (ali njihovi deli) najpogosteje uporabljene v metaforah ${ }^{6}$, aktualiziranih citatih (npr. Skoči brate na medveda! (Pa zakaj?)) ${ }^{7}$ in frazemih (riba smrdi pri glavi; volk sit in koza cela ...). Omeniti velja še (re)termi-

$3 \quad$ Korpus ni lematiziran, zato je bilo pregledovanje, čeprav elektronsko, še vedno zamudno, zanimivi so bili (korpusni) šumi, npr. iskanje sestavine volk, ko se je izkazalo, da je Volk pogost priimek, v nemških citatih je v pomenu 'narod', iskalnik pa zanemarja tudi morebitno razliko med o in ö.

$4 \quad$ Pravna praksa je slovenski pravni časopis in je namenjen v prvi vrsti pravnikom, vendar tudi drugim, ki morajo biti pri svojem delu seznanjeni s strokovnimi in zanesljivimi informacijami. Kot tednik vsebuje tako kolumne kot poglobljene strokovne prispevke z vseh pravnih področij. Izhaja od leta 1982.

5 Pravnik je revija za pravno teorijo in prakso, prvič pa je ižsel že leta 1862 kot Slovenski pravnik (izdajatelj dr. J. R. Razlag), v letih 1870-1872 so izšli trije letniki revije Pravnik slovenski (izdajatelj dr. J. R. Razlag). Leta 1881 je kot 1. letnik izšla revija Slovenski pravnik in nato še leta 1882 in 1883 (izdajatelj dr. Alfonz Mosche). Leta 1888 je izšel 4. letnik revije (izdajatelj društvo Pravnik), ki je nato izhajala (razen v letih 1918 in 1919) do leta 1944. Leta 1946 (kot 1. letnik) je začela izhajati revija Ljudski pravnik, ki se je leta 1953 preimenovala v Pravnik; od 1. januarja 1965, po združitvi z revijo Javna uprava, izhaja Pravnik kot revija za pravno teorijo in prakso, 12 številk na leto pa obsega približno 800 strani.

6 Npr. »Sprevrže se [zakon] v zver, ki kolje po pestrosti življenja, in do nje ne pravnik ne pisatelj ne moreta čutiti ničesar drugega kot večni stud.« (Pravna praksa, 28. 4. 2005, str. 35, poudarki M. J. T.)

7 Gre za naslov ene od kolumn, ki poleg naslova otroške pesmi Otona Župančiča, postavlja vprašanje o regulaciji lova na divje zveri v Sloveniji. 
nologizacijo posameznih izrazov, povezanih z živalskim svetom, npr. model gnezda, zračno gnezdo. ${ }^{8}$

\subsubsection{Frazemi}

V strokovnih/znanstvenih besedilih je raba frazeologije kljub vsemu omejena. Pomemben zunajjezikovni dejavnik je, da se pravniki med seboj (skozi dolgoletno šolanje in potem tudi združevanje $\mathrm{v}$ poklicna združenja, npr. zbornice in društva) povezujejo v relativno (tesno) povezano skupnost, ki temelji (ali vsaj naj bi) na »omikanosti«. ${ }^{9}$ Tako se v strokovnih besedilih pojavi razmeroma presenetljiv obrat - ker je strokovna revija namenjena (skoraj izključno) pravnikom in so pravniki (zelo) izobraženi, si avtorji (lažje) privoščijo stilistične posege v obliki frazemov (tudi živalskih), saj s tem (po njihovem mnenju) argumentacija v strokovnem besedila ne bo okrnjena, celo nasprotno, zaradi stilističnih figur bo njihova argumentacija (in ne interpretacija!) še prepričljivejša, ${ }^{10}$ hkrati pa tako preverjajo tudi kulturno kompetenco naslovnika, če bo ta sposoben prepoznati zapisano. Mednje v prvi vrsti sodijo latinski reki, ki se pojavijo skoraj v vsakem besedilu (!) vsaj enkrat, vendar pa zanimivo med njimi ni najti živalskih frazemov. ${ }^{11}$ Živali so omenjene tudi v prispodobah ali naukih iz antičnih, predvsem Ezopovih, basni, avtorji se razkrivajo tudi z navajanjem živali iz otroške literature (npr. mavrična ribica ${ }^{12}$, kar pa vsaj bralcem, ki nimajo majhnih otrok, ne ponuja pravih asociacij), zanimivo pa ni veliko živalskih frazemov iz Svetega pisma.

Vse sestavine frazemov v strokovnih besedilih morajo biti načeloma besede knjižnega jezika. Pogovornega ali narečnega izrazja pravzaprav sicer ni najti, ${ }^{13}$ lahko pa je rabljen frazem, ki se sicer pogosteje pojavlja v govorjenem jeziku, npr. držati se [pravil]

$\overline{8}$ Gnezda sicer gradijo ptice za valjenje svojih jajc. Model gnezda označuje tip družine, kjer za otroka v lastnem prebivališču izmenično skrbita in ga negujeta oba starša. Zračno gnezdo je geografsko enotno področje glede na relief in značilnosti gibanja zračnih mas.

9 Danes je to evfemistični izraz za kulturo in izobrazbo posameznika. Zagotovo pa temelji na (pomembni) tradiciji, da so prav pravniki (poleg duhovnikov) v 19. stoletju pomembno pripomogli k uveljavljanju slovenskega jezika, prizadevanju za samostojno univerzo itd. Po tradiciji so torej med najbolj (in najširše) izobraženimi predstavniki družbe. Pravniki so bili poleg teologov in zdravnikov ter farmacevtov eni redkih, ki so obvladali latinščino. Današnje stanje je (seveda) drugačno. Znanje latinščine upada in je omejeno na nekatere najpogosteje rabljene pravne reke, ki pa jih tudi današnji študenti prava (dobro) poznajo.

10 Dokaz, da so frazeološki posegi zavestni je npr. v besedilu Marka Pavlihe (PP, 22. 11. 2007, str. 31): »Letošnja jesen se je začela s pridevnikom, ki mu še ne želim vedeti pomena, kakopak zaradi previdnosti, da ne bom napačno tetoviral samostalnika, ki diši po moštu, kostanju, gobah in odpadlem listju. /... / Več ne smem povedati, lahko pa nanizam nekaj slovenskih pregovorov, na katere sem se spomnil med prebiranjem Grishamovega romanopisnega žogobrca in jih malce priredil svoji duši. Morda jih preverite, ko (če) ga boste končali. / .../« Poudarila M. J. T.

11 Tako se npr. ne pojavi homo homini lupus ampak le človek človeku volk.

12 Gre za serijo knjig Marcusa Pfistra o Mavrični ribici, v slovenščini so izšle pri založbi Kres.

13 Redka izjema je npr. »lastna hvala se pod mizo vala« (poudarila M. J. T.), ki je v celoti v navednicah. 
kot pijanec plota, zagnati vik in krik, naj sosedu crkne ${ }^{14} \mathrm{krava}$, en velik lari fari ${ }^{15}$. Pogosteje se pojavljajo živalski frazemi z negativno konotacijo, ${ }^{16}$ kar bi lahko pojasnili tudi s človekovim superiornim odnosom do živali. ${ }^{17}$

Frazemi so lahko rabljeni v celoti (npr. človek človeku volk, grešni kozel, leta debelih krav) ali nakazani le s sestavino (npr. zgrabiti za roge). ${ }^{18}$ Prenovitve frazemov so vedno aktualizirane, zanimivo je njihova aktualizacija uvedena $\mathrm{z}$ istim besedilom. ${ }^{19}$

\section{3 Živalski frazemi v pravnih besedilih}

Moje izhodiščno predvidevanje je bilo, da živalskih frazemov v pravnih besedilih ne bo veliko predvsem zaradi zahteve po strokovnosti. Po drugi strani pa je bilo glede na raznolika besedila mogoče predvidevati, da bodo tiste sestavine frazemov, ki so negativno konotirane, zamenjane z neko blažjo in zato sprejemljivejšo sestavino, npr. osla $\mathrm{v}$ frazemu trmast kot osel bi zamenjal konj. Frazem je sicer po podatkih iz Gigafide tudi sicer razmeroma redek, saj najdemo le 10 zadetkov. S spremembo družbe se je namreč spremenila tudi konotacija pridevnika trmast, nekajkrat tudi z delnim pomenskim ustreznikom vztrajen, ki pa ne tvori frazema ${ }^{*}$ vztrajen kot konj/bik. ${ }^{20}$

\subsection{Osel}

Osel je v splošnem jeziku še vedno močno negativno konotirana beseda, uporablja se tudi kot zmerljivka, zato je tudi redko uporabljena kot sestavina živalskih frazemov.

\subsubsection{Rimski doktor, nemški osel}

Frazem oz. rek je pojasnjen v posebni kolumni, ki predstavlja in razlaga izvor (zanimivih) rimskih rekov.

$\overline{14}$ Gre za uveljavljeno obliko frazema s pomenom 'želeti drugemu slabše (od sebe)'. Zanimivo je tudi, da nikoli noben pisec ni začutil pogovornosti glagola crkniti 'poginiti', da bi ga kakorkoli posebej označil.

15 Navajam obliko, ki je zapisana.

16 Na tem mestu je upravičen pomislek razmerja med pozitivno in negativno konotiranimi živalskimi frazemi v slovenščini.

17 Znani hrvaški pravni teoretik profesor Nikola Visković (ki se je med drugim veliko ukvarjal tudi z jezikom prava) je objavil tudi monografijo Životinja i čovjek. Split: Književni krug. V njej razčlenjuje filozofsko osnovo antropocentričnega prepričanja, po katerem človek (kot edini, ki je »ustvarjen po božji podobi«) na podlagi »pravice močnejšega po svoji volji razpolaga z drugimi bitji kot sredstvi za svoje cilje. Več v Koritnik 2006, 2.

18 Prav primer zgrabiti [bika] za roge kaže, da je možno izpustiti samo sestavino bik, če želi pisec ohraniti pomen frazema.

19 Npr. potopiti bojno sidro ( $\leftarrow$ zakopati bojno sekiro) v zvezi z vprašanjem meje v Piranskem zalivu ali Ovce, ki blejajo na aristokrate, bodo torej zaklane (še preden popasejo travo na mestnem stadionu), potem pa bodo $v$ surovine predelane po ustreznem (pravnem) postopku (PP, 11. 11. 2010, str. 33) v zvezi z upiranjem okoliških prebivalcev do načrtovane obnove ljubljanskega Plečnikovega stadiona.

20 Zanimivo pa se v splošnem referenčnem korpusu Gigafida pojavi nekaj zadetkov kolokacije vztrajen kot želva. 
Vsaj na prvi pogled izraža isto tudi rek Doctor Romanus, asinus Germanicus (Rimski doktor, nemški osel). Z njim so hoteli povedati, da rimski oz. italijanski doktor ne ve nič več kot navaden osel v Nemčiji. Ta dokaj groba primerjava pa ni bila usmerjena $v$ različno kakovostno raven doktoratov. Izšla je iz razsvetljenskih, predvsem protestantskih teoloških krogov, ki so se tako norčevali iz katoliških teologov, še zlasti tistih, ki so bili pristaši tomistične filozofije. (PP, 27. 11. 2008, str. 34)

\subsubsection{Buridanov osel}

Frazem se pojavi le enkrat, gre za odlašanje izbire odločitve, ki privede do nesrečnega zaključka.

Državni svet od prevelikega števila zahtev za zakonodajni referendum, s katerimi bi lahko uspel, medtem ko bi se mu lahko na drugi strani očitalo, da ga je premalokrat uporabil. Tako se znajde v začaranem krogu kot Buridanov osel, ki ne ve, v katero kopico sena bi zagrizel, tako da nazadnje pogine. (Pravnik, 2008, št. 4-6, str. 259)

\subsection{Bik}

Bik se pojavlja pogosteje kot osel, gre za žival, ki predstavlja divjost in moč, čemur ustreza tudi frazem borzni bik.

Država in tudi podjetja bi morala borznega bika lansko leto bolje izkoristiti. Predvsem ko je bilo jasno, da tečaji brzijo navzgor brez pravih podlag. Če tega ne razumejo največji delničarji, potem bi morali vodilni to vsekakor razumeti. (PP, 13. 3. 2008, str. 36)

\subsubsection{Zgrabiti bika za roge}

Razmeroma pogost frazem v pomenu 'lotiti se naloge/problema na pravilen način', katerega oblika se ne spreminja, sestavina bik je lahko zamenjan z zver.

»Uspešno« - ali zgolj zaradi svoje obupne preobremenjenosti z drugim delom ali tudi iz kakšnega še manj opravičljivega razloga, žal ne vem - pa se je Ustavno sodišče vse doslej izmikalo temu, da bi »zgrabilo bika za roge« in zaustavilo prav sramotno kršenje mednarodnega prava in mednarodnih standardov o azilu tako v naši zakonodaji kot ( ̌̌e bolj) pri upravnem in sodnem odločanju o pravicah prosilcev za azil. (PP, 15. 1. 2009, str. 8)

Čeprav zatrjujeva popolno neutemeljenost stališč informacijske pooblaščenke, meniva, da bi ta bolje »zagrabila bika za roge«, če bi zahtevala blokado objavljenih podatkov šele po poteku mandatne dobe predstavniškega organa, za katerega 
je kandidat kandidiral, vendar ne podatkov o osebnem imenu, datumu rojstva in listi. (PP, 22. 12. 2011, V)

\subsubsection{Bik kot grški bog Zevs}

Ob vstopu Slovenije v Evropsko unijo je nastalo nekaj zanimivih zapisov. Med drugim so posamezniki opozarjali tudi na antično pripovedko o lepi Evropi, ki se ji je Zevs približal v podobi bika in jo zapeljal, da mu je rodila potomca, ki je bil pol človek in pol bik.

Zato pozdravljena, Evropa, krasná si, bistra sestra Kadmova, samo za božjo voljo

pazi, da Zevs te zopet ne odpelje v podobi bika ... (PP, 10. 2. 2005, str. 3)

Antično zgodbo obuja tudi naslednji odlomek, ki v rubriki o latinskih rekih predstavlja, da prenašanje težav ves čas s seboj le-teh ne reši.

Milo, quem vitulum adsueverat ferre, taurum ferebat. Rek, ki bi se po naše glasil

»Milo, ki se je navadil nositi tele, je na koncu nosil bika«. (PP, 27. 9. 2012, str. 32)

\subsection{Krava}

Janez Keber v svoji monografiji Živali v prispodobah vse pripadnike goveda obravnava $\mathrm{v}$ istem poglavju. Frazeološko gradivo s sestavino krava bi bilo sicer verjetno redko, vendar je eden od vidnejših slovenskih pravnikov (Boštjan M. Zupančič) izjavil, da je sreča za krave $v$ hlevu, pravo pa za aristokrate, kar je povzročilo precej ponovitev tega citata, hkrati pa spodbudilo tudi rabo drugih frazemov.

\subsubsection{Molzna krava}

Frazem molzna krava vedno označuje posameznika ali skupino ljudi, ki jih drugi izkoriščajo, sami pa ne naredijo ničesar, da bi to preprečili.

Prav tako je bil med razpravo zanimiv komentar Lucijana Bembiča, ki je kot generalni državni pravobranilec opomnil na že izplačanih milijon evrov odškodnine zaradi kršitve pravice do sojenja brez nepotrebnega odlašanja. Pri tem je še izrazil bojazen, da postaja ta postopek pritožbe stalna pravna praksa in Slovenija s tem »redna molzna krava«. (PP, 30. 11. 2006, str. 28)

\subsubsection{Naj sosedu crkne krava}

Ta rek v pomenu škodoželjnosti kot tipične slovenske lastnosti se kar nekajkrat pojavi v pravnih besedilih. 
S tem torej vlagatelju ne bi nastala nobena škoda, saj sam še vedno ne bi bil izbran. Morda bi se sicer po slovenski maniri veselil, da je sosedu crknila krava, a posla ne bi sklenil. (PP, 13. 9. 2007, str. 12)

Pri nas velja reklo, naj sosedu crkne krava, v Ameriki velja, če ima sosed eno, bom jaz imel dve. Ali pa Grčija: če ima sosed kravo, bom pil mleko zastonj. (PP, 10. 4. 2008, str. 39)

V slovenskem narodnem značaju je nekaj paradoksalnega. Po eni strani naj bi veljali za skromne in sramežljive, skorajda kmečke neveste, po drugi pa smo polni lastne hvale. Bili naj bi marljivi, pridni, snažni in pošteni. Tega, kje je dejanska podlaga za takšno oceno, ne vem. Ta mantra izvira iz časov, ko smo bili najrazvitejša republika SFRJ. Primerjali smo se z junaki, ki so nastopali v vicih o Črnogorcih, in najbrž tako ustvarili mit o delavnem narodu. Kdo drug si je o nas mislil drugače. Bili smo kmetavzi, ki na južni strani Karavank z vilami prekladajo gnoj in čakajo, da bo sosedu crknila krava. (PP, 30. 10. 2008, str. 35)

\subsubsection{Leta debelih/suhih krav}

Gre za najpogosteje rabljena svetopisemska frazema, ki sta posebno pogosta $\mathrm{v}$ času od začetka gospodarske krize leta 2008 in pomenita obdobje obilja in obdobje pomanjkanja.

Seveda pa na potrošnika ne prežijo samo višje obresti. Tudi davki bodo odigrali svoje. V letih debelih krav se pri sestavljanju državnih proračunov pogosto nismo spraševali, od kod bo pritekel denar, zdaj pa se pozornost politikov (vsaj domačih) usmerja predvsem v višanje davkov (namesto $\mathrm{v}$ zmanjševanje javne porabe). (PP, 10. 12. 2009, str. 34)

Menim, da bo to treba sprejeti in ljudem povedati, da bo naslednjih nekaj let obdobje »suhih krav«. To pomeni, da bo problem delitve dobrin še težji in zaostren. Če k temu dodamo težave in stroške klimatskih sprememb, je slika še bolj zapletena. (PP, 7. 4. 2011, str. 4)

\subsubsection{Sveta krava}

Frazem pomeni 'nedotakljivo osebo ali stvar'.

Kot se za doktorsko delo spodobi, avtor ne pozna »svetih krav«. Tako na primer in med drugim v sprotni opombi 698 opozori na Milivojevićevo nedoslednost pri njegovih izvajanjih glede kognitivne vsebine čustev jeze oziroma besa. (PP, 7. 7. 2011, str. 28) 


\subsection{Tele}

Frazema s sestavino tele sta le dva, oba sta dobro poznana tudi v splošnem jeziku.

\subsubsection{Gledati kot tele v nova vrata}

Frazem se rabi v pomenu 'začuden'.

Prodajalec me je pogledal na način, ki se opisuje z besedno zvezo »gledal ga je kot tele v nova vrata《. »Stvar je v tem, « sem nadaljeval, »da že latinski rek uči: nemo plus iuris transferre potest ...«(PP, 2. 10. 2008, str. 35)

\subsubsection{Zlato tele}

Izbiblični frazem, ki predstavlja 'čaščenje površnih, nepravih vrednot'.

Po bibličnem izročilu: »Izderite zlate uhane iz ušes svojih žena, sinov in hčera in mi jih prinesite. In vse ljudstvo si je izdrlo zlate uhane iz ušes in ulil je zlato tele«. In sprejeli so zlato fiskalno pravilo. (PP, 10. 5. 2012, str. 33)

\subsection{Pes}

Pričakovanje, da bodo frazemi s sestavino pes pogostejši, se ni potrdilo, saj se pravniki v svojih besedilih vse prepogosto ukvarjajo s pravnimi ureditvami o reji in vzgoji (predvsem nevarnih) psov.

Brez te pravice mediji ne bi mogli izvajati svoje demokratične funkcije oziroma izvajati vloge »javnega psa čuvaja«, ki je postavljena v središče pravice do svobodnega izražanja medijev. (PP, 6. 10. 2005, str. 9)

\subsection{Volk}

\subsubsection{Volk sit in koza cela}

Frazem [tako da] bo volk sit in koza cela, ki se navadno uporablja v prihodnjiku in načinovno, izhaja iz živalskega sveta, $v$ katerem je volk plenilec, zver, ovca pa možna žrtev. Preneseno sestavini volk in koza $\mathrm{v}$ frazemu predstavljata dve zelo različni strani, ki naj bi se dogovorili tako, da bi bilo prav, sprejemljivo za obe, ali pa bi to zanju storili drugi.

Spričo tega bi bilo smiselno, da vsaj VS sprejme kompromisno rešitev, ki bi dopuščala, da bi bil »volk sit in koza cela«. (PP, 16. 6. 2005, str. 13)

Očitno je bilo tudi naših klikov na Daulagiri dovolj in ob neverjetni sponzorski in medijski podpori se je letos lotil naslednjega, nič manj norega projekta. Rezultat je znan: volk sit in koza cela (čeprav bi jo nemara kdo raje videl mrtvo). (PP, 8 . 9. 2005, str. 33) 
Zdravniki ne bodo stavkali. Njihov sindikat je s pristojnima ministroma dosegel dogovor, da bo vlada po najkrajši zakonodajni poti državnemu zboru predlagala spremembe zakona, ki ureja plačni sistem v javnem sektorju. Sporazumna rešitev povsem ustreza pregovoru o celi kozi in sitem volku. (PP, 17. 11. 2005, str. 31)

Vpogled postopka inšpekcijskega organa je pokazal, da je edini vir podatkov in edina resnica, ki ji je inšpekcijski organ brezpogojno priznal verodostojnost in na njej utemeljil svojo odločitev, tista, ki jo je v postopku izustil direktor trpinčenega in odpuščenega J.-ja. Sitemu volku so torej verjeli, da se je jagenjček sam zaklal.

Zadnji primer je zanimiv, ker še podkrepi prej zapisano misel, vendar so tovrstne parafraze redke.

\subsection{2 Človek človeku volk}

Čeprav gre za znani latinski rek homo homini lupus, se v latinščini med gradivom ne pojavi. Rek se sicer vsaj v delu vedno pojavlja v slovenščini, lahko pa je prvi ali zadnji del latinski.

Ne Haag, le sosed bo mejak! ${ }^{21}$ Piškavi sosedski odnosi prežijo nad človeštvom kot prekletstvo, kajti homo sapiens človeku ni le volk, temveč tudi nevoščljivi sosed, kar je še huje, če pomislimo na fizična in sodna obračunavanja glede mejnikov, dovoznih poti, previsokih ograj, gnilega sadja, smrdečih greznic, preglasnih petelinov, nevarnih psov in tako naprej $\mathrm{v}$ neskončno medsebojno nagajanje. (PP, 30. 8. 2007, str. 3)

Poleg tega je tudi vsa moderna legitimacija (upravičenost) državne oblasti utemeljena na teoriji družbene pogodbe, katere bistvo je prav v tem, da ljudje v naravnem stanju spoznajo, da se jim bolj »splača« vso svojo moč prenesti na državo in se podrejati njeni oblasti, kot živeti v boju vseh proti vsem (bellum omni contra omnes), torej v brezdržavnem stanju, kjer je »človek človeku volk«. Pomen reda povzdiguje tudi Goethe: »Bolje, da se tebi zgodi krivica, kot da bi svet ostal brez zakonov!« (PP, 22. 3. 2007, str. 33)

Metaforična raba obeh frazemov, kjer so človeku pripisane lastnosti volka kot zveri, se kaže v naslednjem odlomku:

Volkovi smo. V tropu sledimo toku skupine, z gobci, zašiljenimi naprej, krvoločni v priprtih očeh, in izlakoteni v telesu. Ko gre za druge, smo preračunljivi. Zlo potisnemo v ozadje zavesti s pomočjo slepe vere. Postavljamo se s cinizmom,

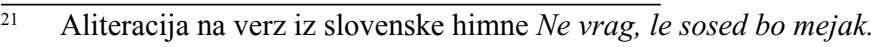


smo cinični volkovi. V tropu nam odpovesta tako razum kot empatija. Predvsem pa smo tiho, grozljivo tiho, ko se klatimo naprej, skozi rog in ne gledamo vstran. Dobri smo, marljivi, hitri. Na obronku gozda se bodo naši zobje zapičili v mlado jagnje. Smejte se mi. (PP, 30. 10. 2008, str. 35)

\subsection{Lisica}

Frazemi, čeprav redki, ki vsebujejo sestavino lisica, so zanimivi, saj je v množinski obliki lisice termin, ki pomeni 'pripravo za vklepanje aretirancev' oz. tudi 'pripravo za vklepanje napačno parkiranih vozil'. ${ }^{22}$ Najpogosteje pa se uporablja frazeološki glagol prelisičiti.

Marsikateri državljan je ponosen na svojega jeklenega konjička, zato mu ni pogodu, ko se mu kdaj pa kdaj v Ljubljani na sprednjo levo pnevmatiko ujame kaka jeklena lisička. (PP, 22. 12. 2005, str. 13)

Sicer pa velja, če sklenem spet z ljudsko modrostjo, da bomo doživeli udejanjenje pregovora: nekaj časa teče zajec, nekaj časa pa lisica. (PP, 6. 4. 2006, str. 20)

\subsection{Koza}

\subsubsection{Grešni kozel}

Zanimivo, da se koza pojavlja samo v frazemu grešni kozel, ki je na Slovenskem še dodatno razširjen in poznan zaradi otroške pripovedke J. Jurčiča Kozlovska sodba $v$ Višnji gori. Ta frazem je med vsemi živalskimi frazemi, ki se pojavljajo v pravnih besedilih, najpogostejši.

V letu 2004 so manjšine igrale vlogo glavnega grešnega kozla za večino slovenskih težav, je opozoril varuh in spomnil na dogajanje ob prizadevanjih muslimanov, da bi zgradili svoj verski center, odnos do Romov in referendum o izbrisanih. (PP, 23. 6. 2005, str. 25)

To, da se ob vsakokratnem odškodninskem primeru $\mathrm{v}$ medijih in na sodišču trdovratno išče nekoga, ki bi mu bilo mogoče pripisati odškodninsko odgovornost (tj. grešnega kozla), ima namreč tudi drugo plat medalje. (PP, 1. 9. 2005, str. 27)

Pogosto odgovorne osebe žrtev mobinga prikažejo kot izključnega krivca oziroma kot grešnega kozla za vse probleme, ki jih sami niso sposobni rešiti. (PP, 30. 3. 2006, str. 19)

$\overline{22} \quad$ Podobno je terminologiziran tudi pajek 'vozilo z žerjavom za odvažanje nepravilno parkiranih vozil' in ne nazadnje tudi žerjav, ki je lahko sicer ptica ali 'naprava za dvigovanje, prenašanje na vrvi obešenih bremen po zraku na manjše razdalje'. Gre pravzaprav za metonimično poimenovanje funkcije ali podobnosti naprave po živali. 
Naj tudi spomnimo: institut preiskovalnega sodnika - tega grešnega kozla vseh naših tegob - je pred leti med prvimi s prepričljivimi argumenti raztrgal dr. Boštjan M. Zupančič in naletel na očitke o amerikanizaciji postopka. (PP, 17. 4. 2008, str. 3)

Vendar pa je valiti krivdo za ostrino finančne krize na propad družbe Lehman Brothers pomanjkljivo, kratkovidno in pomeni iskanje grešnega kozla. (PP, 16.

7. 2009, str. 34)

\subsection{Muha}

Zanimivo je, da se manjše živali ne pojavljajo pogosto, kar lahko utemeljujemo tudi s simbolno močjo oz. vplivom, ki ga imajo na človeka. Muha tako pomeni bolj sitnost in nadlego kot oviro ali pravega nasprotnika.

\subsubsection{Modna muha} nost':

Pojavlja se v pomenu 'nenavadna, pozornost vzbujajoča modna novost ali poseb-

Namen zapisnika prav tako ne more biti neselektivno beleženje celotnega dogajanja na glavni obravnavi. Tak namen bi bil slabo premišljena modna muha, podnetena s siceršnjo vsesplošno (digitalno) vnemo po arhiviranju življenja. (PP, 21. 4. 2011, str. 41)

Če na kratko povzamem, gre za to, da so razne modne muhe na področju prostočasnih dejavnosti »en velik lari fari«. (PP, 28. 8. 2008, str. 31)

\subsubsection{Muha enodnevnica}

Pojavlja se v pomenu 'kar ima majhno, kratkotrajno vrednost'.

Slednje naj bi bil temeljni dokaz o nepovezanosti oziroma o neusklajenosti delovanja. Da to ni bila samo muha enodnevnica, smo lahko opazili tudi na nedavni skupščini družbe Javor Pivka, ki je postregla s pestrim naborom nasprotnih predlogov in tudi napovedanih izpodbojnih tožb. (PP, 10. 7. 2008, str. 36)

\subsection{Kača}

Ne glede na simbolni pomen kače, ki ji je v Svetem pismu pripisan negativni pomen, pa se kača v pravnih besedilih ne pojavlja pogosto. Frazem dolg kot jara kača pa izgubi prvotno negativno konotacijo kače kot živali in pomeni le 'dolgotrajnost'.

Vsebinsko boljša rešitev bi zato bila »dejanje, ki ima znake kaznivega dejanja in je protipravno« - vendar pa ta rešitev boleha za drugo boleznijo: dolga je kot jara 
kača in zato ni v skladu z načelom, naj bo zakonsko besedilo kratko in jedrnato. (PP, 17. 6. 2010, str. 24)

\subsection{Ptice}

\subsubsection{Prva lastovka}

Eden od redkih živalskih frazemov s pozitivno konotacijo je prva lastovka 'kar naznanja nekaj novega, drugačnega', vendar ji je navadno dodan drugi del, ki kaže (vsaj začasno) na neuspešnost nadaljevanja.

Po koncu uspešnega mandata predsednice Ustavnega sodišča dr. Dragice Wedam Lukić, prve lastovke, ki glede zastopanosti žensk ni prinesla pomladi, je ponovno vzpostavljen skoraj popolni monopol moških na najpomembnejših parlamentarnih, vladnih in sodnih institucijah. (PP, 20. 1. 2005, str. 38)

$\mathrm{S}$ tem dejanjem je sledila ukrepom Francije, ki so v strokovni javnosti povzročili mešane odzive. Ti dve lastovki bi lahko bili znanilki prihoda novega pristopa $\mathrm{k}$ sankcioniranju uporabnikov interneta, zato si velja pobližje ogledati, kakšen pristop so uporabili v Združenem kraljestvu in kaj to pomeni za preostale državljane EU. (PP, 20. 5. 2010, str. 15)

\subsubsection{Sraka}

Za razliko od lastovke je sraka že negativno konotirana zaradi svojega oglašanja, zato je tudi rabljena $v$ besedilih na tak način.

Morebitni Sovin posnetek medsebojnega renčanja bi bil prehrupen, pri čemer že poldrugo desetletje najbolj vrečči mejaška sraka! (PP, 30. 8. 2007, str. 3)

\subsection{Slon}

Od živali, ki sicer ne živijo na območju Slovenije, je prisoten slon, vendar ne v frazemu delati iz muhe slona, temveč v primeri kot slon v trgovini s porcelanom.

Ukrep ima izrazito avtoritarno komponento, hkrati pa je $\mathrm{v}$ zakonu koncipiran tako, kot da bi spustili slona $\mathbf{v}$ trgovino s porcelanom (nesorazmernost ukrepa $\mathrm{v}$ zakonu, ki ureja delikatno področje posegov v osebno svobodo). (PP, 24. 2. 2005, str. 20)

$\mathrm{V}$ vse to dogajanje, ki ima pozitivne in negativne plati, vendar naj bi na koncu, $\mathrm{v}$ očeh javnosti, le pripeljalo do večje veljave sodne veje oblasti, pa se z udarci, podobnimi ravnanju slona $\mathbf{v}$ trgovini $\mathbf{s}$ porcelanom, vmešava ministrstvo za upravo. (PP, 22. 3. 2007, str. 35) 


\section{Sklep}

Živalski frazemi so v pravnih strokovnih besedilih redkejši od drugih, predvsem somatskih frazemov (ki so tudi stilno nevtralnejši), vendar se pojavljajo dovolj pogosto, da so opazni. Največkrat se sicer pojavijo v navednicah, vendar ni nujno, na zavestno stilno posebnost pa ne nakazuje niti ležeči tisk, iz česar lahko sklepamo, da so živalski frazemi (vsaj nekateri) za avtorje prav tako del jezika kot termini, ki jih uporabljajo ob njih.

Njihovo mesto ni predvidljivo, največkrat celo niso v vlogi uvodne motivacije ali sklepne misli, temveč se pojavljajo (zgolj) kot podkrepitev izrečenega kjerkoli v besedilu, celo $\mathrm{v}$ kateri koli vrsti besedila, ne le $\mathrm{v}$ kolumnah ali uvodnikih, kjer so sicer najpogostejši.

Živali, ki se pojavljajo, so povezane s slovenskim okoljem, vendar so pogostejše večje živali (ki so tudi sicer bolj na koncu prehranjevalne verige). Zanimivo je opazovati, katerih živali ni. Med njimi ni vola, kar je zagotovo tudi posledica, da vola kot delovne živali v Sloveniji skoraj ne najdemo več, zato je tudi oblika frazema trmast kot vol ${ }^{23}$ redkejša (tudi v splošnem korpusu Gigafida). Pri tem je opazen in nedoločljiv občutek za »knjižnost« ali »strokovnost«, kateri frazemi so še dopustni, zato so bolj kot kvantitativno zanimivi kvalitativni tipi oz. pretvorbe frazemov in njihova (aktualnopolitična) konotacija. ${ }^{24}$

Pomemben podatek je, da se živalski frazemi skoraj ne pojavljajo $\mathrm{v}$ znanstveni periodiki, kar pomeni, da je njihova konotacija vendarle tako izrazita, da se avtorjem njihova raba ne zdi dopustna.

Statistično gledano pa se živalski frazemi pojavljajo pri tistih avtorjih, ki tudi sicer uporabljajo veliko (drugih) frazemov, latinskih citatov in drugih elementov esejističnosti, vendar prav ti avtorji s svojim zgledom spodbudijo tudi druge, da jih (v slogu) posnemajo, sploh ker gre za avtorje, ki so stalni sodelavci revije Pravna praksa že več let.

23 Če lahko vola označimo za žival, ki se je vsaj v preteklosti pojavljala kjer koli v Sloveniji, pa tega ne moremo trditi za istrsko mulo, ki se prav tako pojavlja v primeri trmast kot istrska mula in je $\mathrm{v}$ analiziranih besedilih ni najti.

24 Zanimiv odlomek je npr. »Le nekdanja Mavrična ribica, zdaj skromna in neopazna, se je umaknila pod svojo koralo in potočila jodovo solzo, ker je vedela, da Veverici lahko pomaga le Hobotnica modrijanka, če že ni prepozno.« (PP, 23. 11. 2006, str. 6) Odlomek je del »basni«, kot jo je poimenoval avtor in se dotika vseh aktualnopolitičnih problemov, ki so bili odprti v letu 2006 in oseb, ki so se z njimi ukvarjale $\mathrm{v}$ parlamentu in javnosti. 


\section{LITERATURA}

Gruber, Helmut et al. 2009. Wissenschaftliches Schreiben. Ein Praxisbuch für Studierende. Wien - Köln - Weimar: Böhlau.

Jemec Tomazin, Mateja. 2012. Frazemi v znanstvenih besedilih - območje dopustnega. V: Frazeološka simfonija: sodobni pogledi na frazeologijo. Jakop, Nataša; Jemec Tomazin, Mateja (red.). Ljubljana: Založba ZRC, ZRC SAZU. 81-90.

Keber, Janez. 1996. Živali v prispodobah 1. Celje: Mohorjeva družba.

Keber, Janez. 1998. Živali v prispodobah 2. Celje: Mohorjeva družba.

Kobe, Eva. 2005. Jezikovni stil v časopisnih uvodnikih: slovenski dnevnik »Delo« v primerjavi z italijanskim »La Repubblica«. Diplomsko delo. Fakulteta za družbene vede. Univerza v Ljubljani. Ljubljana.

Koritnik, Boštjan. 2006. Nekaj pogledov na pravno ureditev varstva živali pred mučenjem. Pravna praksa. Priloga. II-VIII. 23. 2. 2006.

Kržišnik, Erika. 2005. Frazeologija v luči kulture. V: Večkulturnost v slovenskem jeziku, literaturi in kulturi. Zbornik predavanj 41. seminarja slovenskega jezika, literature in kulture. Stabej, Marko (red.). Ljubljana: Center za slovenščino kot drugi/tuji jezik pri Oddelku za slovenistiko Filozofske fakultete. 67-81.

Kržišnik, Erika. 2008. Viri za kulturološko interpretacijo frazeoloških enot. Jezik in slovstvo. 53/1: 33-47.

Pravna praksa. Časopis za pravna vprašanja. Ljubljana: GV Založba. [PP]

Pravnik. Revija za pravno teorijo in prakso. Ljubljana: Zveza društev pravnikov Slovenije.

Snoj, Jerica. 2010. Metafora v leksikalnem sistemu. Ljubljana: Založba ZRC, ZRC SAZU.

\section{SLOVARJI}

Slovar slovenski frazemov. 2011. Keber, Janez (red.). Ljubljana: Založba ZRC, ZRC SAZU. [SSF]

\section{SUMMARY}

\section{WHEN IT IS GOOD TO BECOME STUBBORN AS AN OX?}

The paper presents animal phrasems as they appear in professional legal literature. Use of any phraseological units in professional texts still mainly depends on each author separately. But due to the tendency of scientificity, cogency and persuasiveness in each text it is clear that also the eventual use of phraseological units has special requirements which is represented in the cultural connotation of used components which means that there often occurs substitution of animals used in phraseological units if they are to make the text more professional (eg. persistent like a turtle and not persistent as an ox).

Keywords: animal phrasems, phraseological connotation, phraseme components, scientific style, personal style 